\title{
Pengaruh Cairan Pembersih Lumut dan Pupuk Anorganik terhadap Pertumbuhan Tanaman Teh (Camellia Sinensis (L.) O.Kuntze) Asal Biji Setelah Dipangkas
}

\author{
DOI 10.18196/pt.2015.043.78-86 \\ Intan Ratna Dewi Anjarsari \\ Jurusan Budidaya Pertanian, Fakultas Pertanian, Universitas Padjadjaran, \\ Jl. Raya Bandung Sumedang KM 21, Jatinangor 45363, Indonesia, Telp: (022) 7796316, Fax: (022) 7796316, \\ e-mail:intan_rdewi@yahoo.co.id
}

\begin{abstract}
ABSTRAK
Penelitian ini bertujuan untuk menelaah pengaruh cairan pembersih lumut dan pupuk anorganik terhadap pertumbuhan tanaman teh (Camellia sinensis (L.) O.Kuntze) asal biji setelah dipangkas, dilaksanakan di Kebun Percobaan Pusat Penelitian Teh dan Kina Gambung Ciwidey. Rancangan percobaan yang digunakan adalah Rancangan Acak Kelompok (RAK) pola faktorial dengan dua faktor. Faktor pertama adalah konsentrasi cairan pembersih lumut dengan 4 taraf, yaitu 0 (tanpa cairan pembersih lumut), 1\%, 2\%, dan 3\%. Faktor kedua adalah dosis pupuk anorganik dengan 4 taraf, yaitu 100\%, 80\%, 60\%, dan 40\%, sehingga terdapat 16 kombinasi perlakuan dengan 3 ulangan. Hasil percobaan menunjukkan bahwa tidak terdapat pengaruh interaksi antara pemberian cairan pembersih lumut dan pupuk anorganik. Pengaruh mandiri cairan pembersih lumut pada konsentrasi 2\% menunjukkan jumlah tunas, bobot basah pucuk, dan bobot kering pucuk lebih tinggi dibandingkan konsentrasi 1\% dan 3\%. Demikian pula dengan pengaruh mandiri pupuk anorganik, dosis 80\% menunjukkan jumlah tunas, bobot basah pucuk dan bobot kering pucuk yang lebih tinggi dibandingkan dosis 100\%, 60\% dan 40\%.

Kata kunci: Tanaman teh asal biji, Cairan pembersih lumut, Pupuk anorganik
\end{abstract}

\begin{abstract}
A study examines the effect of moss removal and inorganic fertilizers on the growth of the tea (Camellia sinensis (L.) O.Kuntze) derived from seed after pruning. This research was conducted at the Research Center of Tea and Quinine in Gambung, Ciwidey. The research was managed using factorial experiment that arranged in Completely Randomized Design $4 \times 4$ with three replications. The first factor was the concentration of moss removal i.e. 0\%, 1\%, $2 \%$ and 3\%. The second factor was the dose of inorganic fertilizer i.e. 100\%, 80\%, 60\% and 40\%. The result showed that there was no interaction between moss removal and inorganic fertilizer. In $2 \%$ of moss removal showed the better result than 1\% and 3\% of moss removal in shoot numbers, shoot fresh weight, shoot dry weight. Inorganic fertilizer with $80 \%$ doses showed better result than doses 100\%, 60\% and 40\% in shoot numbers, shoot fresh weight, shoot dry weight.

Keywords: Tea derived from seed, moss removal, inorganic fertilizer
\end{abstract}

\section{PENDAHULUAN}

Pakpahan (2000) menyatakan bahwa produksi pengelolaan perkebunan teh. Faktor utama yang perkebunan teh di Indonesia masih sangat rendah dibandingkan dengan negara penghasil teh lainnya. Produksi perkebunan rakyat hanya mencapai $764 \mathrm{~kg} / \mathrm{ha} /$ tahun, jauh di bawah standar yang ditetapkan Lembaga Penelitian Kenya sebesar $1.500 \mathrm{~kg} / \mathrm{ha} /$ tahun. Selanjutnya menurut Malik (2007) bahwa menurunnya produktivitas teh Indonesia sekitar $1.900-2.000 \mathrm{~kg}$ teh mempengaruhi rendahnya produktivitas tanaman adalah sebagian besar kebun-kebun teh mempunyai umur tanaman yang sudah tua, perdu-perdu menderita kerusakan fisik yang cukup berat dan sebagian besar kebun teh berasal dari tanaman asal biji yang tidak diketahui induknya (Astika dkk., 1985).

Pemangkasan adalah salah satu cara yang kering ha/tahun, antara lain disebabkan lambat- dapat ditempuh untuk meningkatkan hasil dan nya peremajaan tanaman dan tidak optimalnya mutu teh. Pemangkasan atau prunning meru- 
pakan manipulasi pertumbuhan tanaman yang dilakukan dengan tujuan untuk mendapatkan keuntungan. Tetapi bagi tanaman, pemangkasan merupakan tindakan yang mengganggu pertumbuhan dan perkembangannya. Oleh sebab itu, harus dilakukan secara hati-hati dan memperhatikan kondisi tanaman itu sendiri supaya tanaman tidak menjadi rusak. Pemupukan adalah pemberian unsur-unsur hara ke dalam tanah dalam jumlah yang sesuai dengan kebutuhan tanaman. Tujuannya untuk meningkatkan daya dukung tanah terhadap pertumbuhan dan produktivitas tanaman. Pupuk yang diberikan dapat berupa pupuk organik maupun pupuk anorganik. Pupuk yang biasa digunakan pada lahan perkebunan teh umumnya adalah pupuk anorganik tunggal yang memiliki kandungan unsur hara N, P, K atau Mg. Pertumbuhan tanaman teh memerlukan hara makro N, P, K, Mg dalam jumlah banyak yang diberikan melalui tanah, dan unsur hara mikro Zn dalam jumlah sedikit yang diberikan dalam bentuk larutan, sehingga produksi tanaman tidak menurun atau bahkan meningkat.

Penyemprotan cairan pembersih lumut diaplikasikan pada tanaman teh asal biji karena sebagian besar tanaman teh menghasilkan (TM) asal biji banyak terserang oleh lumut. Pada cabangcabang perdu teh, khususnya pada tanaman asal biji (seedling), umumnya tumbuh lumut yang dapat mengganggu pertumbuhan tunas baru. Semakin tua umur tanaman tingkat pertumbuhan lumutnya semakin tinggi. Pada tanaman belum menghasilkan (TBM), yakni tanaman teh yang masih muda (berumur di bawah dua tahun) dan belum diambil produksinya (pucuknya) pada umumnya tidak terserang lumut. Cairan pembersih lumut yang digunakan mengandung bahan aktif kapur yang dapat meluruhkan tumbuhan lumut yang dapat mengganggu pertumbuhan tunas baru. Penggunaan zat pembersih lumut produksi Pusat Penelitian Teh dan Kina Gambung telah dicobakan di beberapa kebun, diantaranya Goalpara Sukabumi 12 ha pada tahun 2000, Montaya di Gunung Halu seluas 16 ha pada tahun 2005. Tahun 2007 dilakukan percobaan di perkebunan Bah Butong, Sidamanik dan Tobasari serta Kebun Percobaan Simalungun wilayah PTPN IV di Medan (Sumatera Utara) dengan konsentrasi 2\% (Isdiyanto dan Eko Pranoto, 2007). Hasilnya secara visual menunjukkan bahwa pemberian cairan pembersih lumut tersebut dapat meluruhkan semua jenis lumut yang tumbuh pada batang, cabang dan ranting teh tiga sampai tujuh hari setelah penyemprotan, sehingga diharapkan pertumbuhan tunas tidak terganggu oleh keberadaan lumut tersebut. Penyemprotan cairan akan lebih efektif hasilnya bila dilakukan pada saat kondisi cerah untuk menghindari adanya pencucian oleh air hujan.

Pemberian cairan pembersih lumut dengan pupuk anorganik diharapkan dapat menekan pertumbuhan lumut dan meningkatkan proses fisiologis tanaman teh, dimana terdapat pengaruh interaksi antar kedua perlakuan tersebut yang pada akhirnya dapat mempercepat pertumbuhan tunas, dan hasil tanaman teh. Penyemprotan cairan pembersih lumut dilakukan tiga hari atau lima hari setelah pangkas dengan konsentrasi anjuran 2\% (Salim, 2005).

\section{BAHAN DAN METODE}

Bahan tanaman yang akan digunakan pada penelitian ini tanaman teh menghasilkan (TM) asal biji berumur 48 tahun sebanyak 960 tanaman dengan jarak tanam $110 \mathrm{~cm}$ x $90 \mathrm{~cm}$. Pupuk Urea $(\mathrm{N}), \mathrm{KCl}\left(\mathrm{K}_{2} \mathrm{O}\right)$, SP-36 $\left(\mathrm{P}_{2} \mathrm{O}_{5}\right)$, Kiserit $(\mathrm{MgO})$, dan cairan pembersih lumut produksi 
Pusat Penelitian Teh dan Kina ( PPTK) Gambung.

Alat-alat yang digunakan dalam penelitian ini adalah knapsack sprayer untuk menyemprotkan cairan pembersih lumut, bambu dan plat seng untuk patok percobaan, leaf area meter untuk mengukur luas daun, waring untuk mengangkut pucuk, hand counter untuk menghitung jumlah tunas, amplop kertas yang dilubangi untuk menyimpan sampel pucuk, oven untuk mengeringkan sampel pucuk, timbangan analitik untuk menimbang sampel pucuk dan bobot kering tanaman.

Rancangan percobaan yang digunakan adalah Rancangan Acak Kelompok (RAK) pola faktorial, 2 faktor dengan 3 kali ulangan. Faktor pertama yaitu konsentrasi cairan pembersih lumut (a) dengan 4 taraf : $\mathrm{a}_{1}=$ tanpa cairan pembersih lumut, $\mathrm{a}_{2}=1 \%$ cairan pembersih lumut $(10 \mathrm{~mL} / \mathrm{L}$ atau 3,03 L/plot larutan jadi), $a_{3}=2 \%$ cairan pembersih lumut $(20 \mathrm{~mL} / \mathrm{L}$ atau $3,06 \mathrm{~L} /$ plot larutan jadi), $\mathrm{a}_{4}=3 \%$ cairan pembersih lumut (30 mL/Latau 3,09 L/plot larutan jadi). Faktor kedua yaitu pupuk anorganik (b) dengan 3 taraf : b1= 100\% pupuk tunggal dosis anjuran $(652,17$ g/plot urea, 166,7 g/plot SP-36, 200 g/plot KCl, $222,3 \mathrm{~g} /$ plot Kiserit), b2=80\% pupuk tunggal dosis anjuran (521,74 g/plot urea, 133,36 g/ plot SP-36 160 g/plot KCl, 177,84 g/plot Kiserit), b3-60\% pupuk tunggal dosis anjuran $(391,30 \mathrm{~g} /$ plot urea, 100,02 g/plot SP-36, $120 \mathrm{~g} /$ plot KCl, $133,34 \mathrm{~g} /$ plot Kiserit), b4=40\% pupuk tunggal dosis anjuran $(260,87 \mathrm{~g} /$ plot urea, $66,68 \mathrm{~g} / \mathrm{plot}$ SP-36, $80 \mathrm{~g} /$ plot KCl, 88,92 g/plot Kiserit.

Dengan demikian terdapat 4 × $4=16$ kombinasi perlakuan, seluruh satuan percobaan yang diulang 3 kali menghasilkan 16 × 3 = 48 satuan percobaan. Setiap satuan percobaan terdiri dari 20 tanaman. Jumlah seluruh tanaman 960 tanaman.

\section{HASIL PENELITIAN}

Analisis Tanah Sebelum dan Sesudah Percobaan

Analisis tanah sebelum percobaan menunjukkan tanah ini memiliki pH 4,9 (sedang). Keadaan tersebut sesuai dengan persyaratan yang dibutuhkan untuk pertanaman teh, yaitu pada kisaran 4,5 - 6,0. Hasil analisis tanah sebelum percobaan menunjukkan bahwa tanah yang digunakan untuk percobaan memiliki tekstur lempung berdebu dengan kandungan pasir $13,17 \%$, debu $63,41 \%$ dan liat 23,42\%. Menurut Winarso (2005) tekstur tersebut merupakan tekstur tanah yang mendekati kondisi ideal untuk pertumbuhan tanaman. Kandungan C-organik tinggi $(6,65 \%)$ dan kandungan $\mathrm{N}$-total termasuk sangat tinggi $(0,83 \%)$ dengan rasio $\mathrm{C}$ terhadap $\mathrm{N}$ (C/N) 8,01 (rendah). Rasio C terhadap N yang rendah menunjukkan bahwa tanah memiliki unsur hara yang cukup dan siap digunakan oleh tanaman karena proses pendekomposisian bahan di dalam tanah telah terjadi (Asosiasi Penelitian dan Pengembangan Perkebunan Indonesia, 2002).

Hasil analisis tanah sesudah percobaan menunjukkan bahwa $\mathrm{pH}$ tanah berada pada kisaran 4,8 - 5,0 (sedang), masih sesuai dengan kisaran $\mathrm{pH}$ yang dibutuhkan untuk pertumbuhan tanaman teh. Sementara nilai C-organik tanah sesudah percobaan mengalami penurunan yang berada pada kisaran 6,15 \%- 6,30\%. Demikian pula halnya dengan $\mathrm{N}$-total $(0,67 \%-0,79 \%)$. Namun demikian rasio $\mathrm{C} / \mathrm{N}$ tetap berada pada kisaran 8 -9 seperti pada sebelum percobaan.

\section{Analisis Hara Daun Indung Sebelum dan Sesudah Percobaan}

Daun indung atau mother leaf adalah daun tua pertama tempat percabangan pucuk yang sehat yang telah siap dipetik (manjing), daun indung 
berwarna gelap yang telah mencapai ukuran penuh bila dibandingkan dengan daun-daun tua di bawahnya dan terletak di ketiak tunas yang sedang tumbuh. Kadar unsur hara daun indung dapat menggambarkan keadaan unsur hara tanaman teh secara keseluruhan karena daun indung merupakan tempat terjadinya fotosintesis. Pertumbuhan pucuk sangat ditentukan oleh kadar unsur hara yang terkandung pada daun indung (Asosiasi Penelitian dan Pengembangan Perkebunan Indonesia, 2002).

Hasil analisis sebelum percobaan menunjukkan bahwa kadar N 3,14\% (sedang), P 0,18\% (rendah), K 1,19\% (rendah), Ca 1,57\% (tinggi), Mg 0,28\% (tinggi), S 0,27\% (tinggi), dan Zn 17 ppm (rendah). Hasil analisis sesudah percobaan menunjukkan bahwa kadar $\mathrm{N}$ bervariasi untuk setiap perlakuan, berada pada kisaran 3,01\% - 3,19\% (rendah-sedang), kadar P berada pada kisaran 0,15 - 0,21\% (rendah - sedang), kadar K 0,91\%-1,14\% (sangat rendah - rendah), kadar Ca 1,49\% - 1,69\% (tinggi- sangat tinggi), $\mathrm{Mg}$ 0,22\% - 0,29\% (rendah-sangat tinggi), kadar S 0,22\% - 0,26\% (rendah - sedang), dan Zn 10-24 mg kg ${ }^{1}$ berat kering (rendah).

\section{Hama, Penyakit dan Gulma Selama Percobaan}

Berdasarkan hasil pengamatan, terdapat beberapa hama yang menyerang tanaman teh, diantaranya kepik penghisap daun teh (Helopeltis antonii), wereng penghisap pucuk teh (Empoasca sp.), ulat api (Setora nitens) serta ulat penggulung daun (Homona coffearia). Selama percobaann intensitas serangan hama ringan dan tidak menimbulkan kerusakan yang berarti sehingga pengendaliannya hanya dilakukan dengan cara mekanis tanpa pengendalian secara kimia. Gulma yang tumbuh selama percobaan berlangsung antara lain teki (Cyperus rotundus), babadotan (Ageratum conyzoides), lampuyangan (Panicum repens) dan alang-alang (Imperata cylindrical). Pengendalian gulma dilakukan secara manual pada bulan pertama, sedangkan pada bulan kedua pengendalian dilakukan dengan menggunakan herbisida Roundup dengan dosis $3 \mathrm{~L} / \mathrm{ha}$. Suhu, Kelembaban dan Curah Hujan

Selama percobaan berlangsung, suhu berkisar antara $20,75^{\circ} \mathrm{C}-23,13{ }^{\circ} \mathrm{C}$ dengan kelembaban nisbi 76,50\% - 82,75\%, sedangkan curah hujan sangat rendah yaitu $0,00-8,91 \mathrm{~mm} /$ hari. Curah hujan yang rendah mengakibatkan serangan hama penyakit selama percobaan, penyerapan pupuk yang rendah selama percobaan karena penguapan yang cukup tinggi. Meskipun curah hujan sudah nol produksi pucuk masih dalam kondisi cukup kemudian menurun. Hal tersebut dapat dimengerti bahwa di dataran tinggi pada umumnya jenis tanahnya Andisol dengan bahan organik yang masih cukup tinggi (5\%-6\%) yang mampu mengikat air lebih lama.

\section{Komponen Pertumbuhan: Jumlah tunas}

Hasil analisis statistik pada Tabel 1 menunjukkan bahwa tidak terjadi interaksi antara cairan pembersih lumut dengan pupuk anorganik pada jumlah tunas.

Pemberian cairan pembersih lumut dan pupuk anorganik secara mandiri tidak memberikan pengaruh yang nyata terhadap jumlah tunas pada 6 MSP, 8 MSP, dan 10 MSP (Minggu Setelah Pemangkasan). Pengaruh perlakuan cairan pembersih lumut secara mandiri terlihat umur 7 MSP dan 8 MSP. Perlakuan cairan pembersih lumut $\mathrm{a}_{3}(2 \%)$ pada 7 MSP menghasilkan jumlah tunas lebih tinggi dibandingkan perlakuan lainnya, namun tidak berbeda nyata dengan $\mathrm{a}_{4}(3 \%)$. Pada pengamatan $9 \mathrm{MSP}$, pemberian cairan pembersih lumut pada konsentrasi 2\% ( $\left.a_{3}\right)$ menunjukkan 
Tabel 1. Pengaruh Cairan Pembersih Lumut dan Pupuk Anorganik terhadap Jumlah Tunas

\begin{tabular}{cccccc}
\hline \multirow{2}{*}{ Perlakuan } & \multicolumn{5}{c}{ Jumlah Tunas } \\
\cline { 2 - 6 } & 6 MSP & 7 MSP & 8 MSP & 9 MSP & 10 MSP \\
\hline Cairan Pembersih Lumut (a) & & & & \\
a1 & 215,08 a & $375,08 \mathrm{a}$ & $514,00 \mathrm{a}$ & $578,58 \mathrm{a}$ & $629,75 \mathrm{a}$ \\
a2 & $230,08 \mathrm{a}$ & $377,25 \mathrm{a}$ & $534,17 \mathrm{a}$ & $561,33 \mathrm{a}$ & $630,42 \mathrm{a}$ \\
a3 & $292,08 \mathrm{a}$ & $459,92 \mathrm{~b}$ & $553,83 \mathrm{a}$ & $742,92 \mathrm{~b}$ & $664,67 \mathrm{a}$ \\
a4 & $278,25 \mathrm{a}$ & $412,92 \mathrm{ab}$ & $548,67 \mathrm{a}$ & $580,00 \mathrm{a}$ & $636,92 \mathrm{a}$ \\
Pupuk Anorganik (b) & & & & \\
b1 & $214,67 \mathrm{a}$ & $367,25 \mathrm{a}$ & $457,50 \mathrm{a}$ & $524,75 \mathrm{a}$ & $627,83 \mathrm{a}$ \\
b2 & $282,00 \mathrm{a}$ & $440,08 \mathrm{~b}$ & $616,75 \mathrm{a}$ & $715,00 \mathrm{~b}$ & $640,83 \mathrm{a}$ \\
b3 & $265,33 \mathrm{a}$ & $423,17 \mathrm{~b}$ & $534,92 \mathrm{a}$ & $628,50 \mathrm{ab}$ & $662,17 \mathrm{a}$ \\
b4 & $253,50 \mathrm{a}$ & $394,67 \mathrm{ab}$ & $541,50 \mathrm{a}$ & $594,58 \mathrm{ab}$ & $630,92 \mathrm{a}$ \\
\hline
\end{tabular}

Keterangan: Angka rata-rata vertikal yang ditandai dengan huruf yang sama tidak berbeda nyata menurut Uji jarak Berganda Duncan, á $=0,05$ $\begin{array}{llll}\mathrm{a}_{1}=\text { tanpa cairan pembersih lumut } & \mathrm{b}_{1}=100 \% \text { pupuk anorganik } \\ \mathrm{a}_{2}=1 \% \text { cairan pembersih lumut } & \mathrm{b}_{2}=80 \% \text { pupuk anorganik } \\ \mathrm{a}_{3}=2 \% \text { cairan pembersih lumut } & \mathrm{b}_{3}=60 \% \text { pupuk anorganik } \\ \mathrm{a}_{4}=3 \% \text { cairan pembersih lumut } & \mathrm{b}_{4}=40 \% \text { pupuk anorganik } \\ \text { MSP }=\text { Minggu Setelah Pemangkasan } & & \end{array}$

jumlah tunas yang lebih tinggi dibandingkan perlakuan lainnya. Pemberian pupuk anorganik pada 7 MSP terhadap jumlah tunas menunjukkan bahwa perlakuan $b_{1}(100 \%)$ berbeda nyata dengan perlakuan $b_{2}(80 \%)$ dan $b_{3}(60 \%)$, tetapi tidak berbeda nyata dengan perlakuan $\mathrm{b}_{4}(40 \%)$. Demikian pula halnya jumlah tunas pada 9 MSP, pemberian pupuk anorganik $b_{1}(100 \%)$ berbeda nyata dengan $b_{2}(80 \%)$ terhadap jumlah tunas, tetapi tidak berbeda nyata dengan perlakuan lainnya,

Pada 7 MSP pemberian cairan pembersih lumut menunjukkan pengaruhnya diduga karena pemberian zat pembersih lumut dengan penyemprotan yang dilakukan pada batang perdu teh pada konsentrasi 2\% dapat mengikis lumut yang tumbuh meliputinya, sehingga pertumbuhan tunas tidak terganggu. Pemberian pupuk anorganik dengan dosis $80 \%\left(b_{2}\right)$ ternyata mampu meningkatkan jumlah tunas. Unsur hara yang cukup tersedia dalam tanah akan mengurangi tingkat persaingan tanaman terhadap unsur hara, sehingga memungkinkan tanaman meningkatkan aktivitas fotosintesisnya untuk pertumbuhan tunas-tunas tanaman teh. Tidak adanya pengaruh perlakuan pada $6,8,10 \mathrm{MSP}$, hal tersebut disebabkan perdu tanaman teh yang dipangkas belum menunjukkan pengaruhnya. Pada umur 6 MSP lumut yang tumbuh pada batang perdu belum luruh, sehingga pertumbuhan tunas masih terganggu.

Faktor lain yang diduga berpengaruh terhadap pertumbuhan tunas yang tidak berbeda nyata adalah pemangkasan. Pemangkasan bersih yang dilakukan pada tanaman teh asal biji yang berusia lebih dari 40 tahun diduga menyebabkan bagian-bagian yang masih aktif ikut terbuang. Akibatnya tanaman membutuhkan tenaga yang lebih besar untuk membentuk tunas-tunas baru sebagai aparat fotosintesis. Tetapi sebagai akibat perlakuan pemangkasan bersih, maka yang tertinggal adalah mata tunas yang terletak pada cabang yang lebih tua.

Mata tunas yang terletak pada cabang-cabang yang lebih tua mempunyai sifat dorman yang lebih kuat bila dibandingkan dengan mata tunas yang berada pada cabang-cabang yang lebih muda. Semakin tua kulit batang tanaman, maka 
Tabel 2. Pengaruh Cairan Pembersih Lumut dan Pupuk Anorganik terhadap Bobot Basah Pucuk (g)

\begin{tabular}{|c|c|c|c|c|c|c|c|}
\hline \multirow{2}{*}{ Perlakuan } & \multicolumn{7}{|c|}{ Bobot Basah Pucuk (g) } \\
\hline & $12 \mathrm{MSP}$ & 13 MSP & 14 MSP & 15 MSP & $16 \mathrm{MSP}$ & 17 MSP & $18 \mathrm{MSP}$ \\
\hline \multicolumn{8}{|c|}{ Cairan Pembersih Lumut (a) } \\
\hline a1 & 1158,33 a & 450,00 a & $250,00 \mathrm{a}$ & $358,33 a b$ & 316,67 a & $412,50 \mathrm{a}$ & 379,17 a \\
\hline a2 & $1266,67 \mathrm{a}$ & $541,67 \mathrm{ab}$ & 266,67 a & $345,83 a$ & $341,67 a b$ & 420,83 a & 420,83 a \\
\hline a3 & $1508,33 \mathrm{a}$ & 654,17 b & 283,33 a & $400,00 \mathrm{~b}$ & 404,17 b & $500,00 \mathrm{a}$ & 458,33 a \\
\hline a4 & $1275,00 \mathrm{a}$ & $558,33 a b$ & $275,00 \mathrm{a}$ & $375,00 a b$ & $383,33 a b$ & 487,50 a & 441,67 a \\
\hline \multicolumn{8}{|l|}{ Pupuk Anorganik (b) } \\
\hline b1 & $1241,67 a$ & 512,50 a & $237,50 \mathrm{a}$ & $345,83 a b$ & 370,83 a & 441,67 a & $458,33 \mathrm{~b}$ \\
\hline b2 & $1508,33 \mathrm{a}$ & $700,00 \mathrm{~b}$ & 283,33 a & $425,00 \mathrm{c}$ & 379,17 a & 508,33 a & $483,33 \mathrm{~b}$ \\
\hline b3 & $1320,83 a$ & 491,67 a & $275,00 \mathrm{a}$ & 379,17 b & 375,00 a & $450,00 \mathrm{a}$ & $445,83 a b$ \\
\hline b4 & $1137,50 \mathrm{a}$ & 500,00 a & 279,17 a & 329,17 a & 320,83 a & 420,83 a & $312,50 \mathrm{a}$ \\
\hline
\end{tabular}

Keterangan: Angka rata-rata vertikal yang ditandai dengan huruf yang sama tidak berbeda nyata menurut Uji jarak Berganda Duncan, á $=0,05$

$a_{1}=$ tanpa cairan pembersih lumut $\quad b_{1}=100 \%$ pupuk anorganik

$a_{2}=1 \%$ cairan pembersih lumut $\quad b_{2}=80 \%$ pupuk anorganik

$a^{2}=2 \%$ cairan pembersih lumut $\quad b^{2}=60 \%$ pupuk anorganik

$a_{4}=3 \%$ cairan pembersih lumut $\quad b_{4}^{3}=40 \%$ pupuk anorganik

$\mathrm{a}_{4} \mathrm{MP}$
$=$ Minggu Setelah Pemangkasan

makin banyak pula energi yang dibutuhkan untuk menumbuhkan mata tunas yang terdapat pada cabang tersebut (Kullasegaram dan Kathirravetpillai, 1981). Selain itu semakin tua kulit, maka semakin tua pula mata tunas yang terdapat pada batang teh. Pertumbuhan tunas selain dipengaruhi oleh usia tanaman juga diduga dipengaruhi oleh faktor musim. Faktor musim yang sangat berperan yaitu suhu dan kelembaban udara. Selama percobaan curah hujan sangat rendah, suhu tinggi dan kelembaban berkurang. Pada kondisi tersebut lingkungan tidak menunjang untuk pertumbuhan tunas.

\section{Bobot Basah Pucuk}

Hasil analisis statistik pada Tabel 2 menunjukkan tidak terjadi pengaruh interaksi antara cairan pembersih lumut dengan pupuk anorganik terhadap bobot basah pucuk. Pada pengamatan $15 \mathrm{MSP}$, pemberian cairan pembersih lumut 2\% ( $\left.\mathrm{a}_{3}\right)$ menunjukkan bobot basah lebih tinggi dibandingkan dengan cairan pembersih lumut $1 \%\left(\mathrm{a}_{2}\right)$, namun tidak berbeda nyata dengan pelakuan tanpa cairan pembersih lumut $\left(\mathrm{a}_{1}\right)$ dan
3\% ( $\mathrm{a}_{4}$ ). Pada pengamatan $16 \mathrm{MSP}$, pemberian tanpa cairan pembersih lumut $\left(a_{1}\right)$ berbeda nyata dengan pemberian $2 \%\left(a_{3}\right)$.

Dilihat dari kecepatan pertumbuhan tunas, untuk menghasilkan pucuk petikan agak lambat dan baru dapat dipetik jendangan 12 minggu setelah pemangkasan (12 MSP). Hal tersebut disebabkan oleh kondisi tanaman teh asal biji sudah cukup tua, selain itu cuaca kering dan suhu panas selama percobaan berlangsung diduga menghambat pertumbuhan tunas. Pemberian cairan pembersih lumut belum terlihat pengaruhnya pada pemetikan ke-1 (12 MSP) terjadi karena pupuk belum terurai sempurna dalam tanah, sehingga belum dapat digunakan oleh tanaman secara optimal.

Demikian pula pada pengamatan $14 \mathrm{MSP}$, 17 MSP, dan 18 MSP tidak berbeda nyata. Pada pengamatan $13 \mathrm{MSP}$, menunjukkan bahwa pemberian tanpa cairan pembersih lumut $\left(\mathrm{a}_{1}\right)$ berbeda nyata dengan perlakuan 2\% $\left(\mathrm{a}_{3}\right)$ dan 3\% $\left(a_{3}\right)$, tetapi tidak berbeda nyata dengan pemberian $1 \%\left(\mathrm{a}_{2}\right)$. Pengaruh mandiri perlakuan pupuk anorganik baru terlihat pada 13 MSP, 15 MSP, 
Tabel 3. Pengaruh Cairan Pembersih Lumut dan Pupuk Anorganik terhadap Bobot Kering Pucuk (g)

\begin{tabular}{|c|c|c|c|c|c|c|c|}
\hline \multirow{2}{*}{ Perlakuan } & \multicolumn{7}{|c|}{ Bobot Basah Pucuk (g) } \\
\hline & 12 MSP & 13 MSP & 14 MSP & $15 \mathrm{MSP}$ & $16 \mathrm{MSP}$ & $17 \mathrm{MSP}$ & $18 \mathrm{MSP}$ \\
\hline \multicolumn{8}{|c|}{ Cairan Pembersih Lumut (a) } \\
\hline a1 & $22,59 a$ & $20,24 a$ & 23,15 a & 22,13 a & 24,66 a & 22,72 a & 19,99 a \\
\hline a2 & $23,51 a$ & $20,74 a b$ & $22,74 a$ & $22,93 a b$ & 24,98 a & 23,45 a & $20,25 a$ \\
\hline a3 & $23,89 a$ & $22,86 \mathrm{c}$ & $23,73 a$ & $24,86 c$ & $26,01 \mathrm{a}$ & 24,29 a & $22,40 a$ \\
\hline a4 & 23,82 a & $22,23 \mathrm{bc}$ & 23,54 a & $23,84 b c$ & 25,35 a & 24,06 a & $20,61 \mathrm{a}$ \\
\hline \multicolumn{8}{|l|}{ Pupuk Anorganik (b) } \\
\hline b1 & $22,59 a$ & $21,21 a$ & 23,76 a & 22,71 a & 26,16 a & 23,79 a & $20,58 \mathrm{a}$ \\
\hline b2 & $22,95 \mathrm{a}$ & $23,21 \mathrm{~b}$ & $24,11 a$ & $24,40 \mathrm{~b}$ & 25,29 a & 23,98 a & $21,85 a$ \\
\hline b3 & $23,88 a$ & $20,67 a$ & 22,36 a & $22,53 a$ & 24,86 a & 23,46 a & $20,13 a$ \\
\hline b4 & 24,40 a & 20,97 a & 22,94 a & $24,11 \mathrm{ab}$ & 24,69 a & $23,29 a$ & $20,69 a$ \\
\hline
\end{tabular}

Keterangan: Angka rata-rata vertikal yang ditandai dengan huruf yang sama tidak berbeda nyata menurut Uji jarak Berganda Duncan, á $=0,05$

$\begin{array}{lll}\mathrm{a}_{1}=\text { tanpa cairan pembersih lumut } & \mathrm{b}_{1}=100 \% \text { pupuk anorganik } \\ \mathrm{a}_{2}=1 \% \text { cairan pembersih lumut } & \mathrm{b}_{2}=80 \% \text { pupuk anorganik } \\ \mathrm{a}_{3}=2 \% \text { cairan pembersih lumut } & \mathrm{b}_{3}=60 \% \text { pupuk anorganik } \\ \mathrm{a}_{4}=3 \% \text { cairan pembersih lumut } & \mathrm{b}_{4}=40 \% \text { pupuk anorganik } \\ \text { MSP }=\text { Minggu Setelah Pemangkasan } & & \end{array}$

dan 18 MSP. Perlakuan pupuk organik 80\% $\left(b_{2}\right)$ pada 13 MSP menunjukkan bobot basah lebih tinggi dibandingkan perlakuan lainnya. Pada 15 MSP, pemberian pupuk anorganik $80 \%\left(b_{2}\right)$ menunjukkan bobot basah lebih tinggi. Hal tersebut menunjukkan bahwa pemberian pupuk anorganik sebanyak $80 \%$ masih bisa memenuhi kebutuhan unsur hara tanaman untuk pertumbuhan pucuknya. Adanya intensitas penyinaran cukup menyebabkan proses fotosintesis berjalan optimal. Selain itu, hal tersebut menunjukkan bahwa pemberian cairan pembersih lumut dapat menghemat 20\% pupuk anorganik, bahkan dapat mencapai 40\%. Pada $18 \mathrm{MSP}$, pemberian pupuk anorganik 100\%, 80\% dan 60\% tidak menunjukkan pengaruh yang nyata terhadap bobot basah pucuk.

Penyemprotan cairan pembersih lumut pada perdu teh di lapangan pada dasarnya meluruhkan lumut yang tumbuh pada batang yang mengganggu pertumbuhan tunas sebagai bakal pucuk yang akan dipetik. Hal tersebut terlihat dari pertumbuhan pucuk peko yang cukup seragam pada saat jendangan pertama dilakukan, yaitu 12 MSP. Faktor lain yang menyebabkan tidak berbeda nyata pemberian cairan pembersih lumut dan pupuk anorganik diduga, karena energi sudah terlalu banyak dipakai untuk tumbuh tunas pucuk sebelum dipangkas.

Produksi pucuk dipengaruhi juga oleh musim. Menurut Sukasman (1997), kejadian tersebut berhubungan dengan curah hujan dan kelembaban udara yang berpengaruh pada keseimbangan air dalam tanah dan tanaman. Jika kelembaban udara optimal, fotosintat mengalir ke pucuk dan cadangan dibongkar, tetapi jika kondisi sebaliknya, maka sebagian besar mengalir ke akar sebagai cadangan dan pertumbuhan pucuk terhambat. Menurut Sutaryanto (1989) bahwa periodisitas tumbuh pucuk ditentukan oleh rasio $\mathrm{C}$ terhadap $\mathrm{N}(\mathrm{C} / \mathrm{N})$ di dalam tanaman teh itu sendiri. $\mathrm{C} / \mathrm{N}$ yang rendah menyebabkan tanaman teh mengalami fase pucuk peko.

\section{Bobot Kering Pucuk}

Hasil analisis statistik pada Tabel 3 menunjukkan tidak terjadi pengaruh interaksi antara 
cairan pembersih lumut dengan pupuk anorganik terhadap bobot kering pucuk.

Secara mandiri, pengaruh pemberian cairan pembersih lumut terhadap bobot kering pucuk terlihat pada 13 MSP dan 15 MSP. Pada 13 MSP dan $15 \mathrm{MSP}$, pemberian cairan pembersih lumut $2 \%\left(a_{3}\right)$ berbeda nyata dengan tanpa cairan pembersih lumut $\left(\mathrm{a}_{1}\right)$, namun tidak berbeda nyata dengan pemberian $3 \%\left(a_{4}\right)$. Pengaruh mandiri pupuk anorganik baru terlihat pada pada pengamatan 13 MSP dan 15 MSP. Pada 13 MSP Pemberian pupuk organik sebesar $80 \%\left(b_{2}\right)$ memberikan bobot kering lebih tinggi dibandingkan dengan perlakuan lainnya.

Pengamatan 15 MSP menunjukkan bahwa pemberian pupuk anorganik $80 \%\left(\mathrm{~b}_{2}\right)$ berbeda nyata dengan perlakuan $100 \%\left(b_{1}\right)$ dan $60 \%\left(b_{3}\right)$, namun tidak berbeda nyata dengan pemberian pupuk anoarganik sebesar $40 \%\left(b_{4}\right)$. Pemberian pupuk anorganik sebesar $80 \%$ masih dapat meningkatkan bobot kering pucuk. Tidak terdapatnya perbedaan yang nyata bobot kering pucuk pada pemetikan ke-1, 3, 5, 6, dan 7 atau pengamatan ke 12 MSP, 14 MSP,16 MSP, 17 MSP dan 18 MSP, diduga karena faktor penyerapan air dan unsur hara yang sangat terbatas pada musim kemarau. Curah hujan pada masa tersebut berada pada kisaran yang lebih kecil bila dibandingkan dengan curah hujan pada 13, 15 MSP.

Keterbatasan air pada saat curah hujan rendah selain menyebabkan pupuk yang diberikan tidak larut dan tidak diserap akar tanaman, juga menyebabkan terjadinya penurunan kecepa$\tan$ fotosintesis pada daun pemeliharaan. Saat kelembaban tanah kurang, tanaman kehilangan air lebih banyak dibandingkan yang dapat diserap oleh akar, sehingga daun akan mulai layu dan stomata menutup, fotosintesis menjadi menurun. Berkurangnya fotosintesis akan me- nyebabkan berkurangnya produksi karbohidrat. Untuk menyerap unsur hara, akan memerlukan karbohidrat sebagai energi sehingga kekurangan air pada tanaman berakibat berkurangnya penyerapan $\mathrm{CO}_{2}$, air dan hara tanaman. Menurut Loveless (1991), kekurangan air akan menyebabkan dehidrasi protoplasma dalam daun, sehingga lambat laun stomata akan menutup dan akibatnya pengambilan $\mathrm{CO}_{2}$ menjadi terhambat.

\section{SIMPULAN DAN SARAN}

\section{Simpulan}

1. Pemberian cairan pembersih lumut dan pupuk anorganik berrpengaruh terhadap pertumbuhan tanaman teh asal biji setelah dipangkas

2. Pengaruh mandiri cairan pembersih lumut menunjukkan bahwa konsentrasi 2\% memberikan jumlah tunas (komponen hasil) serta bobot basah pucuk dan bobot kering pucuk (hasil) lebih tinggi dibandingkan konsentrasi $1 \%$ dan 3\%. Demikian pula dengan pengaruh mandiri pupuk anorganik, dosis $80 \%$ menunjukkan jumlah tunas, bobot basah pucuk dan bobot kering pucuk yang lebih tinggi dibandingkan dosis 100\%, 60\% dan 40\%.

Saran

1. Perlu dilakukan penelitian lebih lanjut mengenai efektivitas pemberian cairan pembersih lumut dan pupuk anorganik pada tanaman teh lebih muda (di bawah umur 48 tahun) guna melihat pengaruhnya terhadap pertumbuhan dan hasil tanaman teh.

2. Disarankan waktu pengamatan yang diperpanjang serta perlu diperhatikan cara pemberian pupuk anorganik dan cairan pembersih lumut dengan memperhatikan kondisi lingkungan di lapangan guna melihat pengaruh yang signifikan. 


\section{DAFTAR PUSTAKA}

Arkat Agus Salim 2005. Basmilum -A2 Sebagai Alternatif Pengendalian Picisan (Cyclophorus nummulari folius) pada Tanaman Teh di Kebun Percobaan PPTK Gambung. Laporan Penelitian (Tidak Dipublikasikan). Hal 1-6.

Asosiasi Penelitian dan Pengembangan Perkebunan Indonesia. 2002. Petunjuk Kultur Teknis Teh. Pusat Penelitian dan Pengembangan Perkebunan, Gambung. Bandung. 191 hal.

Insyaf Malik. 2007. Prospek Cerah Komoditi Teh. Tersedia Online di http://www.nafed.go.id Diakses 17 November 2007.

Isdiyanto dan Eko Pranoto. 2007. Basmilum -A2 Sebagai Alternatif Pengendalian Picisan (Cyclophorus nummularifolius) pada Tanaman Teh di Kebun Percobaan Simalungun, Sumatera Utara. Laporan Penelitian (Tidak Dipublikasikan). Hal 1-4.

Kullasegaram dan Kathirravetpillai. 1981. The Effect of Severity of Pruning on Growth and Yield Of High Country Seed Tea (Camellia Sinensis L.). Tea Q SO (1):16-25

Loveless, A.R. 1991. Prinsip-prinsip Biologi Tumbuhan untuk Daerah Tropik 1 Penerbit PT Gramedia Pustaka Utama : Jakarta

Pakpahan,A. 2000. Program Pembangunan Perkebunan di Indonesia. Prosiding Pertemuan Teknis Teh Nasional. Bandung, 8-9 November 1999. PPTK, Gambung. Hal 3-11.

Sugeng Winarso. 2005. Kesuburan Tanah ; Dasar Kesehatan dan Kualitas Tanah. Penerbit Gava Media. Yogyakarta. Hal 94-110.

Astika, W., D. Muchtar dan Sutrisno. 1985. Klon-Klon Baru Hasil Persilangan Buatan pada Tanaman Teh (Camellia sinensis). Lokakarya Teh Bandung 6(3/4):70-71

Sukasman. (1997). Peran Suhu Kelembaban Udara pada Budidaya Teh dan Faktor-Faktor yang Berpengaruh. Warta Pusat Penelitian Teh dan Jina. 8:55 